\title{
Conversion Therapy in Gastric Cancer - Curative Intent in Stage IV Patients is Beneficial
}

\section{Dillip Kumar Muduly}

All India Institute of Medical Sciences - Bhubaneswar https://orcid.org/0000-0001-6427-5714

Mohammed Imaduddin ( $\square$ imad612@gmail.com)

All India Institute of Medical Sciences - Bhubaneswar https://orcid.org/0000-0001-8398-8840

Mahesh Sultania

All India Institute of Medical Sciences - Bhubaneswar

Sudipta Mohakud

All India Institute of Medical Sciences - Bhubaneswar

Manas Kumar Panigrahi

All India Institute of Medical Sciences - Bhubaneswar

Saroj Kumar Das Majumdar

All India Institute of Medical Sciences - Bhubaneswar

Susama Patra

All India Institute of Medical Sciences - Bhubaneswar

Madhabananda Kar

All India Institute of Medical Sciences - Bhubaneswar

\section{Research Article}

Keywords: Stomach Neoplasm, Neoadjuvant therapy, Conversion therapy, Neoplasm metastasis, Stage IV

Posted Date: January 31st, 2022

DOI: https://doi.org/10.21203/rs.3.rs-1295205/v1

License: (c) (i) This work is licensed under a Creative Commons Attribution 4.0 International License. Read Full License 


\section{Abstract \\ Background}

Stage IV Gastric cancer is associated with a poor prognosis and is often managed with palliative chemotherapy. Conversion therapy in gastric cancer is a growing concept in the treatment of stage IV gastric cancer, wherein an R0 resection is attempted following neoadjuvant chemotherapy. The present studied aimed to evaluate the role of conversion therapy in gastric cancer.

\section{Methods}

Retrospective analysis of a surgical database was performed. Clinically stage IV patients who received chemotherapy were divided into Group 1 with R0 resection (conversion surgery group) and Group 2 without R0 resection (Stage IV noncurative). Upfront operated stage III patients were identified as Group 3. The primary endpoint was overall survival.

\section{Results}

The database included 212 gastroesophageal patients, of which 47 patients were eligible for conversion therapy. Group 1 included 26 patients, Group 221 patients and Group 343 patients. The overall survival of Group 1 was significantly higher when compared with Group 2 (p-value: 0.03 ; HR: 2.14 with 95\% Cl: 1.04 -4.39). The overall survival in Group 3 was higher when compared to Group 1 but did not attain statistical significance ( $p$-value: 0.30 ; HR: 1.44 with $95 \%$ Cl: $0.71-2.90)$.

\section{Conclusion}

Stage IV gastric cancer has improved survival and offers a chance at potential cure if R0 resection is achieved after neoadjuvant chemotherapy. This group of patients have similar survival to upfront resected stage III gastric cancer patients treated with curative intent.

\section{Introduction}

Gastric cancer is the fifth most frequently diagnosed cancer and the third leading cause of cancer-related mortality worldwide.[1] Surgical resection is the mainstay of treatment and offers the only hope of a cure. However, unlike in Japan, the absence of screening protocols for gastric cancer in various countries leads to a delayed presentation where surgical resection may not be feasible, and chemotherapy is often offered as palliative chemotherapy.[2, 3] Presentation with non-specific symptoms and delays in referral for endoscopy further contribute to delayed diagnosis and advanced stage on presentation.[4,5]

According to the National Cancer Database, the median survival of clinical-stage IV (T4b and $\mathrm{M}+$ ) gastric cancer patients is 6-7 months.[6] An analysis of Shizuoka Cancer Centre data has shown that the median survival of clinical-stage IV patients increases to 13.3 months after curative or palliative surgery.[6] The REGATTA trial studied the role of gastrectomy in the presence of metastasis but found no advantage over chemotherapy alone. The trial, however, did not perform an R0 resection, and lymphadenectomy was restricted to D1.[7] This has led to the development of the concept of conversion therapy in gastric cancer. It is defined as the use of chemotherapy followed by surgical resection of a tumour that was previously considered unresectable or metastatic.[8]

The present study aimed to evaluate the benefit of conversion surgery in stage IV gastric cancer patients at a tertiary care centre.

\section{Methodology}

A retrospective analysis of the gastro-oesophageal cancer surgical oncology database at a single institute was performed. Patients with histologically proven stage IV, adenocarcinoma of the stomach, clinically unresectable (T4b) or with limited metastasis (M1), who received neoadjuvant chemotherapy and underwent surgery with a preoperative curative intent were considered eligible as conversion therapy. Stage IV patients that underwent R0 resection were identified as conversion surgery population (Group 1), and stage IV patients who underwent R1, R2 or no resection were identified as Group 2. Patients with histologically proven adenocarcinoma of the stomach operated upfront without neoadjuvant chemotherapy and pathologically stage III was identified as curative stage III population (Group 3). Limited metastasis included para-aortic node involvement, resectable liver metastasis and resectable focal peritoneal involvement. Curative surgery was defined as gastrectomy (Distal, Subtotal, Proximal or Total) with D2 lymphadenectomy and resection of other involved sites achieving an R0 resection.

The primary study endpoint was overall survival. Secondary endpoints included disease-free survival and factors influencing survival in the conversion surgery population. Overall survival was defined as the period from the date of diagnosis to the last follow-up or death date. Disease-free survival was defined as the period from the date of surgery to the date of last follow-up, recurrence or death. Mortality was defined as death due to any cause.

Statistical analysis was performed using STATA software Version 11 (StataCorp LP, TX). Survival data were analysed using Kaplan-Mier survival estimates. The overall survival was compared using the cox proportional hazards. Factors influencing overall survival in the conversion surgery population was analysed using the log-rank test.

The institutional ethics committee approved the study protocol. The study was conducted per the principles of the Declaration of Helsinki and the International Conference on Harmonization Good Clinical Practice Guideline. 


\section{Results}

From April 2016 to May 2021, 212 gastro-oesophageal cancer patients underwent surgical intervention. Forty-seven patients were diagnosed as clinically stage IV, advised neoadjuvant chemotherapy and planned for surgery with a preoperative curative intent. Among these, 26 patients achieved R0 resection (55.3\%) and were identified as Group 1, and 21 patients (44.7\%) were identified as Group 2. Group 3 included 43 patients. [Figure 1]

The median age of the conversion surgery population $(n=26)$ was 53 years (Range: $23-70)$ with a male to female ratio of 1.6:1. Pancreatic involvement $(61.5 \%)$ was the most common cause of classifying as clinically stage IV. EOX (Epirubicin, oxaliplatin and capecitabine) and DOX (Docetaxel, oxaliplatin and capecitabine) regimens were used most commonly as the neoadjuvant regimen (38.5\% each). [Table 1] Post-surgery, most patients were staged as ypStage III (50\%). [Table 2] One patient (3.8\%) had postoperative mortality.

In Group 1, after a median follow-up of 17.4 months, 15 patients (57.7\%) had died. The median overall survival was 18.4 months, with a 3-year overall survival rate of $28.5 \%$. [Table 3] The overall survival of Group 1 was significantly higher when compared with Group 2 (p-value: 0.03 ; HR: 2.14 with $95 \%$ Cl: $1.04-4.39$ ). [Figure 2A] The overall survival in Group 3 was higher when compared to Group 1 but did not attain statistical significance ( $p$-value: $0.30 ; \mathrm{HR}: 1.44$ with 95\% Cl: 0.71 - 2.90). [Figure 2A] The disease-free survival was also higher in Group 3 when compared to Group 1 but did not attain statistical significance ( $p$-value: 0.09 ; HR: 1.76 with $95 \% \mathrm{Cl}: 0.90$ - 1.76). [Figure 2B]

The median overall survival in Group 1 on using DOX and EOX regimen was 29.7 and 17.7 months, respectively, which was significantly better compared to the 9.6 months with FLOT regimen (p-value: 0.004). Age, gender, histological differentiation, lymphovascular invasion, perineural invasion, lymph node ratio and perinodal extension were not found to influence survival in the conversion surgery population. [Table 4]

\section{Discussion}

The study included 47 patients eligible for conversion surgery. Most of the patients had pancreatic involvement (55.3\%) followed by para-aortic node involvement (21.2\%). R0 resection was achieved in 26 patients (55.3\%). The overall survival in stage IV patients with R0 resection was significantly higher than those who did not have an R0 resection with a 3-year survival rate of $28.5 \%$ and $5.9 \%$, respectively ( $p$-value: 0.03 ). The overall and disease-free survival of stage IV patients with R0 resection was not statistically different from stage III upfront curative patients.

Stage IV gastric cancer is associated with a dismal prognosis, and the treatment is limited in most cases to palliative chemotherapy.[9] Several chemotherapy regimens have been studied in advanced gastric cancer, and based on the SPIRITS trial, S1 plus cisplatin is now considered the first-line option in Japan. [10] Despite the advances in chemotherapy protocols, the median overall survival in stage IV gastric cancer remains less than one year, with the intent of treatment still being considered palliative.[11,12] Surgery is the only modality that can offer a chance to cure gastric cancer but is often not feasible in advanced gastric cancer. The addition of targeted agents to chemotherapy has shown benefits, but it is still not a curative option.[13,14]

Surgery in advanced gastric cancer is usually recommended for symptom palliation, palliative resections for bleeding or bypass procedures for outlet obstruction.[15] Surgery as a means to decrease the tumour burden has been studied. The REGATTA trial evaluated the role of upfront gastrectomy in patients with a single non-curable factor without addressing the metastatic lesions and adequate lymphadenectomy. No survival benefit was seen in performing gastrectomy prior to chemotherapy compared to chemotherapy alone.[7] This has led to the development of conversion therapy, a novel approach to treat advanced gastric cancer patients. Patients are subjected to neoadjuvant chemotherapy followed by surgery to attain R0 resection.

Several investigators have evaluated the role of conversion therapy in advanced gastric cancer. [Table 5] The median overall survival in patients undergoing conversion therapy has ranged from 11 months to as high as 62 months.[8,16] The studies have included a heterogeneous group of patient populations, including T4b lesions, para-aortic nodes, limited peritoneal metastasis, positive peritoneal cytology, resectable hepatic metastasis and ovarian metastasis. The focus of these studies has been to achieve an R0 resection and has consistently shown a significant survival benefit over patients treated with chemotherapy alone.[8,17-19]

Yoshida et al. have classified advanced gastric cancer into four categories. Categories one and two include technically resectable metastasis and marginally resectable metastasis, respectively. These categories of patients are suitable to be considered as candidates of conversion therapy and advised neoadjuvant chemotherapy. Category three and four include potentially unresectable and non-curable metastasis involving peritoneum and other organ metastases. Categories 3 and 4 are usually not considered as candidates for conversion surgery.[20]

Attaining R0 resection is the single most important prognostic factor in conversion therapy.[18] The R0 resection rates in patients undergoing surgical intervention after neoadjuvant chemotherapy has been reported to range from $24-100 \%$. $[8,17,21-26]$ The presence of a single noncurative factor is associated with higher rates of R0 resection.[16] The R0 resection rate in the present study was $55.3 \%$ which was similar to several other studies.[17,19,26]

The median overall survival of patients with a successful conversion surgery in the present study was 18.4 months, significantly higher than the patients treated with chemotherapy alone. Though the median overall survival was less when compared to the stage III population, the difference was not statistically significant. This indicates that the conversion surgery cohort is a group of patients with good biology that behaves similar to the stage III population. Clinicpathological characteristics did not significantly correlate with survival outcomes of stage IV patients with R0 resection in the present study. Along with R0 resection, several studies have identified tumour size less than $5 \mathrm{~cm}$, downstaging of the nodal stage, complete or partial response of metastatic sites, one noncurative factor and a decrease in CEA levels to be associated with good prognosis in patients undergoing conversion therapy.[16,27-30]

The choice of a chemotherapy regimen in conversion therapy has not been uniform in most studies. As most of the studies have been reported from Japan, $\mathrm{S} 1$ has been a component of most trials.[16,19,24,28,31] Few investigators have studied the role of specific chemotherapy regimens, but there is no head to

Page $3 / 12$ 
head comparison of different regimens.[22,32,33] The present study showed a significant survival advantage of EOX and DOX regimen over FLOT, but this could be biased due to the small sample size. Institutional guidelines may be followed in deciding the optimal chemotherapy regimen for conversion therapy.

The present study carries several limitations. The study is a retrospective analysis of the surgical oncology database and does not include data pertaining to patients that did not respond to neoadjuvant chemotherapy. The cohort is a biologically heterogeneous group, and the small sample size limits the evaluation of surgical protocol. Patient treatment decisions were made on a case by case basis after discussion in the institutional tumour board and therefore had a lack of uniformity in chemotherapy regimens, number of cycles and timing of surgery.

In conclusion, stage IV gastric cancer, after neoadjuvant chemotherapy, if R0 resection is achieved, confers an improved survival and offers a chance at a potential cure. This group of patients have similar survival to upfront resected stage III gastric cancer patients treated with curative intent. Further studies are required to consolidate the optimal chemotherapy regimen and identify the patient population that would benefit most from conversion therapy.

\section{Declarations}

Declaration of Interest: None

Conflict of Interest Statement: The authors declare that they have no conflict of interest.

Funding: This research did not receive any specific grant from funding agencies in the public, commercial, or not for profit sectors.

Data Availability Statement: The data that support the findings of this study are available from the corresponding author upon reasonable request.

\section{Author Contributions:}

Dr. Dillip K Muduly: Conceptualization, Methodology, Validation, Formal analysis, Resources, Data curation, Writing - Original Draft, Supervision

Dr. Mohammed Imaduddin: Conceptualization, Methodology, Formal analysis, Data curation, Writing - Original Draft, Visualisation

Dr. Mahesh Sultania: Conceptualization, Methodology, Data curation, Writing - Original Draft

Dr. Sudipta Mohakud: Data curation, Writing - Review and Editing

Dr. Manas Kumar Panigrahi: Conceptualization, Methodology, Writing - Review and Editing

Dr. Saroj Kumar Das Majumdar: Validation, Methodology, Writing - Review and Editing

Dr. Susama Patra: Methodology, Writing - Review and Editing

Dr. Madhabananda Kar: Conceptualization, Methodology, Validation, Formal analysis, Resources, Data curation, Writing - Original Draft, Writing - Review and Editing, Supervision

\section{References}

1. Bray F, Ferlay J, Soerjomataram I, Siegel RL, Torre LA, Jemal A. Global cancer statistics 2018: GLOBOCAN estimates of incidence and mortality worldwide for 36 cancers in 185 countries. CA Cancer J Clin. 2018;68:394-424. doi:10.3322/caac.21492.

2. Mahar AL, Coburn NG, Karanicolas PJ, Viola R, Helyer LK. Effective palliation and quality of life outcomes in studies of surgery for advanced, non-curative gastric cancer: a systematic review. Gastric Cancer Off J Int Gastric Cancer Assoc Jpn Gastric Cancer Assoc. 2012;15(Suppl 1):138-45. doi:10.1007/s10120-011-0070-0.

3. Shen L, Shan Y-S, Hu H-M, Price TJ, Sirohi B, Yeh K-H, et al. Management of gastric cancer in Asia: resource-stratified guidelines. Lancet Oncol. 2013;14:e535-47. doi:10.1016/S1470-2045(13)70436-4.

4. Hosseini SN, Mousavinasab SN, Moghimi MH, Fallah R. Delay in diagnosis and treatment of gastric cancer: from the beginning of symptoms to surgeryan Iranian study. Turk J Gastroenterol Off J Turk Soc Gastroenterol. 2007;18:77-81.

5. Maconi G, Manes G, Porro GB. Role of symptoms in diagnosis and outcome of gastric cancer. World J Gastroenterol WJG. 2008;14:1149-55. doi:10.3748/wjg.14.1149.

6. Ajani J, In H, Sano T, Gaspar L, Erasmus J, Tang L, et al. Stomach. 2017. 203-20. doi:10.1007/978-3-319-40618-3_17.

7. Fujitani K, Yang H-K, Mizusawa J, Kim Y-W, Terashima M, Han S-U, et al. Gastrectomy plus chemotherapy versus chemotherapy alone for advanced gastric cancer with a single non-curable factor (REGATTA): a phase 3, randomised controlled trial. Lancet Oncol. 2016;17:309-18. doi:10.1016/S14702045(15)00553-7.

8. Ramos MFKP, Pereira MA, Charruf AZ, Dias AR, Castria TB de, Barchi LC, et al. CONVERSION THERAPY FOR GASTRIC CANCER: EXPANDING THE TREATMENT POSSIBILITIES. Arq Bras Cir Dig ABCD Braz Arch Dig Surg. 2019;32: e1435. doi:10.1590/0102-672020190001e1435.

9. Sano T, Aiko T. New Japanese classifications and treatment guidelines for gastric cancer: revision concepts and major revised points. Gastric Cancer Off J Int Gastric Cancer Assoc Jpn Gastric Cancer Assoc. 2011;14:97-100. doi:10.1007/s10120-011-0040-6.

10. Koizumi W, Narahara H, Hara T, Takagane A, Akiya T, Takagi M, et al. S-1 plus cisplatin versus S-1 alone for first-line treatment of advanced gastric cancer (SPIRITS trial): a phase III trial. Lancet Oncol. 2008;9:215-21. doi:10.1016/S1470-2045(08)70035-4.

Page 4/12 
11. Boku N, Yamamoto S, Fukuda H, Shirao K, Doi T, Sawaki A, et al. Fluorouracil versus combination of irinotecan plus cisplatin versus S-1 in metastatic gastric cancer: a randomised phase 3 study. Lancet Oncol. 2009;10:1063-9. doi:10.1016/S1470-2045(09)70259-1.

12. Van Cutsem E, Moiseyenko VM, Tjulandin S, Majlis A, Constenla M, Boni C, et al. Phase III study of docetaxel and cisplatin plus fluorouracil compared with cisplatin and fluorouracil as first-line therapy for advanced gastric cancer: a report of the V325 Study Group. J Clin Oncol Off J Am Soc Clin Oncol. 2006;24:4991-7. doi:10.1200/JC0.2006.06.8429.

13. Wilke H, Muro K, Van Cutsem E, Oh S-C, Bodoky G, Shimada Y, et al. Ramucirumab plus paclitaxel versus placebo plus paclitaxel in patients with previously treated advanced gastric or gastro-oesophageal junction adenocarcinoma (RAINBOW): a double-blind, randomised phase 3 trial. Lancet Oncol. 2014;15:1224-35. doi:10.1016/S1470-2045(14)70420-6.

14. Bang Y-J, Van Cutsem E, Feyereislova A, Chung HC, Shen L, Sawaki A, et al. Trastuzumab in combination with chemotherapy versus chemotherapy alone for treatment of HER2-positive advanced gastric or gastro-oesophageal junction cancer (ToGA): a phase 3, open-label, randomised controlled trial. Lancet Lond Engl. 2010;376:687-97. doi:10.1016/S0140-6736(10)61121-X.

15. Lordick F, Siewert JR. Recent advances in multimodal treatment for gastric cancer: a review. Gastric Cancer Off J Int Gastric Cancer Assoc Jpn Gastric Cancer Assoc. 2005;8:78-85. doi:10.1007/s10120-005-0321-z.

16. Fukuchi M, Mochiki E, Ishiguro T, Kumagai Y, Ishibashi K, Ishida H. Prognostic Significance of Conversion Surgery Following First- or Second-line Chemotherapy for Unresectable Gastric Cancer. Anticancer Res. 2018;38:6473-8. doi:10.21873/anticanres.13010.

17. Beom S-H, Choi YY, Baek S-E, Li S-X, Lim JS, Son T, et al. Multidisciplinary treatment for patients with stage IV gastric cancer: the role of conversion surgery following chemotherapy. BMC Cancer. 2018;18. doi:10.1186/s12885-018-4998-X.

18. Ishigami S, Natsugoe S, Nakajo A, Matsumoto M, Uenosono Y, Arigami T, et al. Salvage gastrectomy following a combination of biweekly paclitaxel and S1 for stage IV gastric cancer. J Gastrointest Surg Off J Soc Surg Aliment Tract. 2008;12:1370-5. doi:10.1007/s11605-008-0539-2.

19. Yamaguchi K, Yoshida K, Tanahashi T, Takahashi T, Matsuhashi N, Tanaka Y, et al. The long-term survival of stage IV gastric cancer patients with conversion therapy. Gastric Cancer. 2018;21:315-23. doi:10.1007/s10120-017-0738-1.

20. Yoshida K, Yamaguchi K, Okumura N, Tanahashi T, Kodera Y. Is conversion therapy possible in stage IV gastric cancer: the proposal of new biological categories of classification. Gastric Cancer. 2016;19:329-38. doi:10.1007/s10120-015-0575-Z.

21. Yamaguchi S, Kanetaka K, Maruya Y, Kobayashi S, Adachi T, Hidaka M, et al. [A Case of Unresectable Gastric Cancer with Paraaortic Lymph Node Metastasis Treated with Conversion Therapy]. Gan To Kagaku Ryoho. 2021;48:717-9.

22. Uemura N, Kikuchi S, Sato Y, Ohnuma H, Okamoto K, Miyamoto H, et al. A phase Il study of modified docetaxel, cisplatin, and S-1 (mDCS) chemotherapy for unresectable advanced gastric cancer. Cancer Chemother Pharmacol. 2017;80:707-13. doi:10.1007/s00280-017-3404-8.

23. Morgagni P, Solaini L, Framarini M, Vittimberga G, Gardini A, Tringali D, et al. Conversion surgery for gastric cancer: A cohort study from a western center. Int J Surg Lond Engl. 2018;53:360-5. doi:10.1016/j.jjsu.2018.04.016.

24. Sato Y, Ohnuma H, Nobuoka T, Hirakawa M, Sagawa T, Fujikawa K, et al. Conversion therapy for inoperable advanced gastric cancer patients by docetaxel, cisplatin, and S-1 (DCS) chemotherapy: a multi-institutional retrospective study. Gastric Cancer Off J Int Gastric Cancer Assoc Jpn Gastric Cancer Assoc. 2017;20:517-26. doi:10.1007/s10120-016-0633-1.

25. Yamaguchi K, Yoshida K, Tanaka Y, Matsuhashi N, Tanahashi T, Takahashi T. Conversion therapy for stage IV gastric cancer-the present and future. Transl Gastroenterol Hepatol. 2016;1. doi:10.21037/tgh.2016.05.12.

26. Yano M, Shiozaki H, Inoue M, Tamura S, Doki Y, Yasuda T, et al. Neoadjuvant chemotherapy followed by salvage surgery: effect on survival of patients with primary noncurative gastric cancer. World J Surg. 2002;26:1155-9. doi:10.1007/s00268-002-6362-0.

27. Han D-S, Suh Y-S, Kong S-H, Lee H-J, Im S-A, Bang Y-J, et al. Outcomes of surgery aiming at curative resection in good responder to induction chemotherapy for gastric cancer with distant metastases. J Surg Oncol. 2013;107:511-6. doi:10.1002/jso.23284.

28. Kanda T, Yajima K, Kosugi S-I, Ishikawa T, Ajioka Y, Hatakeyama K. Gastrectomy as a secondary surgery for stage IV gastric cancer patients who underwent S-1-based chemotherapy: a multi-institute retrospective study. Gastric Cancer Off J Int Gastric Cancer Assoc Jpn Gastric Cancer Assoc. 2012;15:235-44. doi:10.1007/s10120-011-0100-y.

29. Yabusaki H, Nashimoto A, Matsuki A, Aizawa M. Significance of surgical treatment in multimodal therapy for stage IV highly advanced gastric cancer. Hepatogastroenterology. 2013;60:377-81. doi:10.5754/hge12653.

30. Ito S, Oki E, Nakashima Y, Ando K, Hiyoshi Y, Ohgaki K, et al. Clinical significance of adjuvant surgery following chemotherapy for patients with initially unresectable stage IV gastric cancer. Anticancer Res. 2015;35:401-6.

31. Saito M, Kiyozaki H, Takata O, Suzuki K, Rikiyama T. Treatment of stage IV gastric cancer with induction chemotherapy using S-1 and cisplatin followed by curative resection in selected patients. World J Surg Oncol. 2014;12:406. doi:10.1186/1477-7819-12-406.

32. Mieno H, Yamashita K, Hosoda K, Moriya H, Higuchi K, Azuma M, et al. Conversion surgery after combination chemotherapy of docetaxel, cisplatin and S1 (DCS) for far-advanced gastric cancer. Surg Today. 2017;47:1249-58. doi:10.1007/s00595-017-1512-Z.

33. Xu Z, Hu C, Yu J, Du Y, Hu P, Yu G, et al. Efficacy of Conversion Surgery Following Apatinib Plus Paclitaxel/S1 for Advanced Gastric Cancer With Unresectable Factors: A Multicenter, Single-Arm, Phase II Trial. Front Pharmacol. 2021;12:642511. doi:10.3389/fphar.2021.642511.

34. Suzuki T, Tanabe K, Taomoto J, Yamamoto H, Tokumoto N, Yoshida K, et al. Preliminary trial of adjuvant surgery for advanced gastric cancer. Oncol Lett. 2010;1:743-7. doi:10.3892/ol_00000130.

35. Satoh S, Okabe H, Teramukai S, Hasegawa S, Ozaki N, Ueda S, et al. Phase Il trial of combined treatment consisting of preoperative S-1 plus cisplatin followed by gastrectomy and postoperative S-1 for stage IV gastric cancer. Gastric Cancer Off J Int Gastric Cancer Assoc Jpn Gastric Cancer Assoc. 2012;15:61-9. doi:10.1007/s10120-011-0066-9.

Page 5/12 
36. Kim SW. The result of conversion surgery in gastric cancer patients with peritoneal seeding. J Gastric Cancer. 2014;14:266-70. doi:10.5230/jgc.2014.14.4.266.

37. Einama $\mathrm{T}$, Abe H, Shichi S, Matsui $\mathrm{H}$, Kanazawa $\mathrm{R}$, Shibuya $\mathrm{K}$, et al. Long-term survival and prognosis associated with conversion surgery in patients with metastatic gastric cancer. Mol Clin Oncol. 2017;6:163-6. doi:10.3892/mco.2017.1128.

38. Solaini L, Ministrini S, Bencivenga M, D'Ignazio A, Marino E, Cipollari C, et al. Conversion gastrectomy for stage IV unresectable gastric cancer: a GIRCG retrospective cohort study. Gastric Cancer Off J Int Gastric Cancer Assoc Jpn Gastric Cancer Assoc. 2019;22:1285-93. doi:10.1007/s10120-019-00968-2.

39. Li W, Jiang H, Yu Y, Wang Y, Wang Z, Cui Y, et al. Outcomes of gastrectomy following upfront chemotherapy in advanced gastric cancer patients with a single noncurable factor: a cohort study. Cancer Manag Res. 2019;11:2007-13. doi:10.2147/CMAR.S192570.

\section{Tables}

Table 1: Patient characteristics of study groups 


\begin{tabular}{|c|c|c|c|}
\hline \multirow[t]{2}{*}{ Characteristic } & Group1 & Group 2 & Group 3 \\
\hline & $n=26$ & $\mathrm{n}=21$ & $n=43$ \\
\hline Age (Median) & 53 years (Range: $23-70$ ) & 55 years (Range: $35-74)$ & 57 years (Range: $30-80$ ) \\
\hline Gender (Male: Female) & $16: 10$ & $14: 7$ & $28: 15$ \\
\hline \multicolumn{4}{|l|}{ ECOG } \\
\hline 0 & $3(11.5 \%)$ & $2(9.5 \%)$ & $4(9.3 \%)$ \\
\hline 1 & $18(69.2 \%)$ & $14(66.7 \%)$ & $35(81.4 \%)$ \\
\hline 2 & $1(3.8 \%)$ & $4(19.0 \%)$ & $1(2.3 \%)$ \\
\hline Unknown & $4(15.4 \%)$ & $1(4.8 \%)$ & $3(6.9 \%)$ \\
\hline \multicolumn{4}{|l|}{ Co-morbidities } \\
\hline Hypertension & $3(11.5 \%)$ & $2(9.5 \%)$ & $13(30.2 \%)$ \\
\hline Coronary artery disease & $2(7.7 \%)$ & $1(4.8 \%)$ & $2(4.6 \%)$ \\
\hline Diabetes Mellitus & $1(3.8 \%)$ & $1(4.8 \%)$ & $1(2.3 \%)$ \\
\hline Hypothyroidism & $1(3.8 \%)$ & - & $4(9.3 \%)$ \\
\hline \multicolumn{4}{|l|}{ Clinical stage } \\
\hline IVA & $22(84.6 \%)$ & $11(52.4 \%)$ & - \\
\hline IVB & $4(15.4 \%)$ & $10(47.6 \%)$ & \\
\hline \multicolumn{4}{|l|}{ Stage IV features } \\
\hline Pancreatic involvement & $16(61.5 \%)$ & $10(47.6 \%)$ & \\
\hline Diaphragm involvement & $5(19.2 \%)$ & $1(4.8 \%)$ & \\
\hline Liver involvement & $4(15.3 \%)$ & $2(9.5 \%)$ & \\
\hline Aorta involvement & $1(3.8 \%)$ & - & - \\
\hline Transverse colon & - & $1(4.8 \%)$ & \\
\hline Para-aortic nodes & $3(11.5 \%)$ & $7(33.3 \%)$ & \\
\hline Liver metastasis & $1(3.8 \%)$ & $1(4.8 \%)$ & \\
\hline Peritoneal metastasis & - & $1(4.8 \%)$ & \\
\hline \multicolumn{4}{|l|}{ Neoadjuvant regimen ${ }^{a}$} \\
\hline EOX & $10(38.5 \%)$ & $6(28.6 \%)$ & \\
\hline DOX & $10(38.5 \%)$ & $9(34.6 \%)$ & - \\
\hline FLOT & $5(19.2 \%)$ & $5(19.2 \%)$ & \\
\hline PC & $1(3.8 \%)$ & $1(4.8 \%)$ & \\
\hline \multicolumn{4}{|l|}{ Procedure } \\
\hline Distal gastrectomy & $4(15.4 \%)$ & $3(14.3 \%)$ & $20(46.5 \%)$ \\
\hline Subtotal gastrectomy & $6(23.1 \%)$ & $1(4.8 \%)$ & $8(18.6 \%)$ \\
\hline Proximal gastrectomy & $2(7.7 \%)$ & - & $1(2.3 \%)$ \\
\hline Total gastrectomy & $14(53.8 \%)$ & $1(4.8 \%)$ & $14(32.5 \%)$ \\
\hline Gastro-jejunostomy & - & $6(28.6 \%)$ & - \\
\hline Feeding jejunostomy & - & $2(9.5 \%)$ & - \\
\hline Exploration alone & - & $8(38.1 \%)$ & - \\
\hline Operative duration & $265 \min (S D:+/-53 \mathrm{~min})$ & $129 \min (S D:$ +/- $95 \min )$ & $272 \min (S D:+/-85 \min )$ \\
\hline Blood loss & 271 ml (SD: +/- 148ml) & $116 \mathrm{ml}(\mathrm{SD}:+/-104 \mathrm{ml})$ & $306 \mathrm{ml}$ (SD: +/- 172ml) \\
\hline 30-day Postop-mortality & $1(3.8 \%)$ & - & $2(4.6 \%)$ \\
\hline
\end{tabular}

aDOX: Docetaxel, oxaliplatin and capecitabine; EOX: Epirubicin, oxaliplatin and capecitabine; FLOT: 5-fluorouracil, leucovorin, oxaliplatin and docetaxel; PC: Paclitaxel and carboplatin 
Table 2: Histopathological characteristics of group 1 and group 3

\begin{tabular}{|c|c|c|}
\hline \multirow[t]{2}{*}{ Characteristic } & Group1 & Group 3 \\
\hline & $n=26$ & $n=43$ \\
\hline \multicolumn{3}{|l|}{ Differentiation } \\
\hline Well differentiated & $3(11.5 \%)$ & $7(16.3 \%)$ \\
\hline Moderately differentiated & $5(19.2 \%)$ & $7(16.3 \%)$ \\
\hline Poorly differentiated & $15(57.7 \%)$ & $25(58.1 \%)$ \\
\hline Unknown & $3(11.5 \%)$ & $4(9.3 \%)$ \\
\hline \multicolumn{3}{|l|}{ Lymphovascular invasion } \\
\hline Yes & $15(57.7 \%)$ & $37(88.1 \%)$ \\
\hline Unknown & $3(11.5 \%)$ & $1(2.3 \%)$ \\
\hline \multicolumn{3}{|l|}{ Perineural invasion } \\
\hline Yes & $18(69.2 \%)$ & $29(69.0 \%)$ \\
\hline Unknown & $3(11.5 \%)$ & $1(2.3 \%)$ \\
\hline Lymph node ratio & Median 0.15 (Range: 0 - 0.92) & Median 0.3 (Range: $0.02-0.89$ ) \\
\hline \multicolumn{3}{|l|}{ Extra-nodal extension } \\
\hline Yes & $6(23.1 \%)$ & $27(62.7 \%)$ \\
\hline Unknown & $16(61.5 \%)$ & $2(4.6 \%)$ \\
\hline \multicolumn{3}{|l|}{ pT } \\
\hline T1 & - & $1(2.3 \%)$ \\
\hline $\mathrm{T} 2$ & $5(19.2 \%)$ & - \\
\hline T3 & $16(61.5 \%)$ & $15(34.5 \%)$ \\
\hline $\mathrm{T} 4$ & $5(19.2 \%)$ & $27(62.8 \%)$ \\
\hline \multicolumn{3}{|l|}{$\mathrm{pN}$} \\
\hline No & $4(15.4 \%)$ & - \\
\hline N1 & $8(30.8 \%)$ & $3(6.9 \%)$ \\
\hline N2 & $4(15.4 \%)$ & $6(13.9 \%)$ \\
\hline N3 & 10 (38.5\%) & 34 (79.1\%) \\
\hline \multicolumn{3}{|l|}{ pStage } \\
\hline I & $2(7.7 \%)$ & - \\
\hline II & $8(30.8 \%)$ & - \\
\hline III & $13(50.0 \%)$ & $43(100 \%)$ \\
\hline IV & $3(11.5 \%)$ & - \\
\hline
\end{tabular}

Table 3: Comparison of survival data of different groups 


\begin{tabular}{|llll|}
\hline & Group 1 & Group 2 & Group 3 \\
& $\begin{array}{l}\text { Conversion surgery } \\
\mathrm{n}=26\end{array}$ & $\begin{array}{l}\text { Noncurative Stage IV } \\
\mathrm{n}=21\end{array}$ & $\begin{array}{l}\text { Curative Stage III } \\
\mathrm{n}=43\end{array}$ \\
\hline Median follow up & 17.4 months (4-59) & 9.3 months (4-29) & 15 months (1-62) \\
\hline Mortality & $15(57.7 \%)$ & $16(76.2 \%)$ & $17(39.5 \%)$ \\
\hline Recurrence & $8(30.7 \%)$ & - & $8(18.6 \%)$ \\
\hline Median Overall survival & 18.4 months & 11.5 months & 31.4 months \\
\hline 3 year overall survival & $28.5 \%$ & $5.9 \%$ & $36.8 \%$ \\
\hline Median Disease-free survival & 12.4 months & - & 28.6 months \\
\hline 3 year Disease-free survival & $22.3 \%$ & - & $28.8 \%$ \\
\hline
\end{tabular}

Table 4: Factors influencing overall survival in the conversion surgery group (log-rank test)

\begin{tabular}{|c|c|c|c|c|}
\hline Factor & $\mathrm{n}$ & Mortality & Median overall survival (months) & $\mathrm{p}$-value \\
\hline Age $(n=26)$ & & & & 0.89 \\
\hline Age $<50$ & 10 & 5 & 17.7 & \\
\hline Age $\geq 50$ & 16 & 10 & 18.4 & \\
\hline Gender $(n=26)$ & & & & 0.86 \\
\hline Male & 16 & 9 & 20.8 & \\
\hline Female & 10 & 6 & 17.7 & \\
\hline Neoadjuvant regimen $(n=26)$ & & & & 0.004 \\
\hline EOX & 10 & 4 & 17.7 & \\
\hline DOX & 10 & 5 & 29.7 & \\
\hline FLOT & 5 & 5 & 9.6 & \\
\hline PC & 1 & 1 & $\mathrm{NR}^{*}$ & \\
\hline Differentiation $(n=23)$ & & & & 0.93 \\
\hline Well & 3 & 2 & 29.7 & \\
\hline Moderate & 5 & 3 & 17.1 & \\
\hline Poor & 15 & 7 & 18.4 & \\
\hline Lymphovascular invasion $(n=23)$ & & & & 0.18 \\
\hline Yes & 15 & 10 & NR & \\
\hline No & 8 & 3 & 17.1 & \\
\hline Perineural invasion $(n=23)$ & & & & 0.83 \\
\hline Yes & 18 & 10 & 18.4 & \\
\hline No & 5 & 3 & 15.2 & \\
\hline Lymph node ratio $(n=24)$ & & & & 0.78 \\
\hline$<0.5$ & 21 & 12 & 18.4 & \\
\hline$\geq 0.5$ & 3 & 2 & 15.2 & \\
\hline Perinodal extension $(n=10)$ & & & & 0.55 \\
\hline Yes & 6 & 4 & 18.4 & \\
\hline No & 4 & 1 & 17.7 & \\
\hline
\end{tabular}

*NR: Not reached 


\begin{tabular}{|c|c|c|c|c|c|c|c|c|c|c|c|}
\hline \multirow{2}{*}{$\begin{array}{l}\text { Author, } \\
\text { Year }\end{array}$} & \multirow[t]{2}{*}{ Country } & \multirow{2}{*}{$\begin{array}{l}\text { No. of } \\
\text { patients }\end{array}$} & \multicolumn{5}{|c|}{ Unresectability characteristics } & \multirow{2}{*}{$\begin{array}{l}\text { Neoadjuvant } \\
\text { Chemotherapy }\end{array}$} & \multirow{2}{*}{$\begin{array}{l}\text { D2 } \\
\text { dissection } \\
(\%)^{b}\end{array}$} & \multirow{2}{*}{$\begin{array}{l}\text { R0 } \\
\text { resection } \\
(\%)\end{array}$} & \multirow{2}{*}{$\begin{array}{l}\mathrm{Mec} \\
\text { OS } \\
\text { (mo }\end{array}$} \\
\hline & & & $\mathrm{T} 4 \mathrm{~b}$ & $\begin{array}{l}\text { Para- } \\
\text { aortic } \\
\text { nodes }\end{array}$ & $\begin{array}{l}\text { Peritoneal } \\
\text { metastasis }\end{array}$ & $\begin{array}{l}\text { Liver } \\
\text { metastasis }\end{array}$ & Others & & & & \\
\hline $\begin{array}{l}\text { Yano et al. } \\
\text { 2002[26] }\end{array}$ & Japan & 33 & $\begin{array}{l}12 \\
(36.4 \%)\end{array}$ & $\begin{array}{l}10 \\
(30.3 \%)\end{array}$ & $26(78.8 \%)$ & $4(12.1 \%)$ & $\begin{array}{l}1 \\
(3.0 \%)\end{array}$ & $\begin{array}{l}\text { 5-FU + epirubicin + } \\
\text { methotrexate + } \\
\text { cisplatin (or) } \\
\text { pirarubicin }+5 \text {-FU + } \\
\text { leucovorin + cisplatin } \\
+ \text { mitomycin C. }\end{array}$ & NR & $24.2 \%$ & NR \\
\hline $\begin{array}{l}\text { Ishigami et } \\
\text { al. } \\
2008[18]\end{array}$ & Japan & 18 & - & $\begin{array}{l}8 \\
(44.4 \%)\end{array}$ & $9(50 \%)$ & $5(27.8 \%)$ & - & S1 + Paclitaxel & $83.3 \%$ & $77.8 \%$ & 25. \\
\hline $\begin{array}{l}\text { Suzuki et } \\
\text { al. } \\
2009[34]\end{array}$ & Japan & 20 & $3(15 \%)$ & $9(45 \%)$ & $6(30 \%)$ & $6(30 \%)$ & $1(5 \%)$ & S-1 + Docetaxel & NR & $45 \%$ & $28 . t$ \\
\hline $\begin{array}{l}\text { Satoh et al. } \\
2012[35]\end{array}$ & Japan & 44 & $\begin{array}{l}2 \\
(4.5 \%)\end{array}$ & $\begin{array}{l}7 \\
(15.9 \%)\end{array}$ & $15(34.1 \%)$ & $4(9.1 \%)$ & $\begin{array}{l}1 \\
(2.3 \%)\end{array}$ & $\mathrm{S} 1+$ Cisplatin & $82 \%$ & $59 \%$ & 19.2 \\
\hline \multirow{2}{*}{$\begin{array}{l}\text { Kanda et } \\
\text { al. } \\
2012[28]\end{array}$} & \multirow[t]{2}{*}{ Japan } & \multirow[t]{2}{*}{28} & \multirow[t]{2}{*}{$\begin{array}{l}9 \\
(32.1 \%)\end{array}$} & \multirow[t]{2}{*}{$\begin{array}{l}15 \\
(53.6 \%)\end{array}$} & \multirow[t]{2}{*}{$7(25 \%)$} & \multirow[t]{2}{*}{$4(14.3 \%)$} & \multirow[t]{2}{*}{-} & $\begin{array}{l}\text { S1 alone (or) S1 + } \\
\text { cisplatin (or) }\end{array}$ & \multirow[t]{2}{*}{$60.7 \%$} & \multirow[t]{2}{*}{$92.9 \%$} & \multirow[t]{2}{*}{29.} \\
\hline & & & & & & & & $\begin{array}{l}\text { S1 + paclitaxel (or) S1 } \\
+ \text { irinotecan }\end{array}$ & & & \\
\hline $\begin{array}{l}\text { Han et al. } \\
\text { 2013[27] }\end{array}$ & Korea & 34 & - & $\begin{array}{l}15 \\
(44.1 \%)\end{array}$ & $5(14.7 \%)$ & $4(11.8 \%)$ & $\begin{array}{l}1 \\
(2.9 \%)\end{array}$ & $\begin{array}{l}\text { 5-FU + Platinum (or) } \\
\text { Taxane + 5-FU + } \\
\text { Platinum }\end{array}$ & $100 \%$ & $76.5 \%$ & $22 . \varsigma$ \\
\hline $\begin{array}{l}\text { Kim et al. } \\
2014[36]\end{array}$ & Korea & 18 & - & - & $18(100 \%)$ & - & - & $\begin{array}{l}\text { 5-FU + } \\
\text { cisplatin (or) Titanium } \\
\text { silicate1 + cisplatin. }\end{array}$ & $100 \%$ & $55.6 \%$ & $37 .($ \\
\hline $\begin{array}{l}\text { Saito et al. } \\
2014[31]\end{array}$ & Japan & 13 & $\begin{array}{l}2 \\
(15.4 \%)\end{array}$ & $\begin{array}{l}4 \\
(30.8 \%)\end{array}$ & $3(23.1 \%)$ & - & $\begin{array}{l}4 \\
(30.8 \%)\end{array}$ & $\mathrm{S} 1+$ Cisplatin & $100 \%$ & $81.2 \%$ & $53 . \mathrm{c}$ \\
\hline \multirow[t]{2}{*}{$\begin{array}{l}\text { Ito et al. } \\
2015[30]\end{array}$} & \multirow[t]{2}{*}{ Japan } & \multirow[t]{2}{*}{14} & \multirow[t]{2}{*}{-} & \multirow[t]{2}{*}{$\begin{array}{l}2 \\
(14.3 \%)\end{array}$} & \multirow[t]{2}{*}{12 (85.7\%) } & \multirow[t]{2}{*}{-} & \multirow[t]{2}{*}{$\begin{array}{l}2 \\
(14.3 \%)\end{array}$} & $\begin{array}{l}\text { S1 alone (or) S1 + } \\
\text { cisplatin (or) }\end{array}$ & \multirow[t]{2}{*}{ NR } & \multirow[t]{2}{*}{$100 \%$} & \multirow[t]{2}{*}{24} \\
\hline & & & & & & & & $\begin{array}{l}\text { S1 + docetaxel (or) } \\
\text { Paclitaxel }\end{array}$ & & & \\
\hline \multirow{2}{*}{$\begin{array}{l}\text { Fukuchi et } \\
\text { al. } \\
2015[16]\end{array}$} & Japan & 40 & $6(15 \%)$ & 14 & $11(27.5 \%)$ & $5(12.5 \%)$ & - & $\mathrm{S} 1$ + cisplatin (or) & NR & $80 \%$ & $62 . c$ \\
\hline & & & & & & & & $\mathrm{S} 1+$ paclitaxel & & & \\
\hline $\begin{array}{l}\text { Sato et al. } \\
2017[24]\end{array}$ & Japan & 33 & $\begin{array}{l}7 \\
(21.2 \%)\end{array}$ & $\begin{array}{l}18 \\
(54.5 \%)\end{array}$ & $9(27.3 \%)$ & $6(18.2 \%)$ & $\begin{array}{l}5 \\
(15.2 \%)\end{array}$ & $\begin{array}{l}\text { Docetaxel + cisplatin } \\
+ \text { S- } 1 \text { therapy }\end{array}$ & $100 \%$ & $85 \%$ & $47 . \varsigma$ \\
\hline $\begin{array}{l}\text { Mieno et } \\
\text { al. } \\
\text { 2017[32] }\end{array}$ & Japan & 31 & $\begin{array}{l}8 \\
(25.8 \%)\end{array}$ & $\begin{array}{l}18 \\
(58.1 \%)\end{array}$ & $8(25.8 \%)$ & $5(16.1 \%)$ & - & $\begin{array}{l}\text { Docetaxel + cisplatin } \\
+ \text { S-1 therapy }\end{array}$ & $61.3 \%$ & $74 \%$ & 56.1 \\
\hline $\begin{array}{l}\text { Yamaguchi } \\
\text { et al. } \\
2018[19]\end{array}$ & Japan & 84 & $\begin{array}{l}72 \\
(85.7 \%)\end{array}$ & $\begin{array}{l}28 \\
(33.3 \%)\end{array}$ & $35(41.7 \%)$ & $20(23.8 \%)$ & - & $\begin{array}{l}\text { Docetaxel + cisplatin } \\
+ \text { S-1 therapy }\end{array}$ & NR & $51 \%$ & 41. \\
\hline $\begin{array}{l}\text { Einama et } \\
\text { al. } \\
2017[37]\end{array}$ & Japan & 10 & $1(10 \%)$ & $5(50 \%)$ & $2(20 \%)$ & $1(10 \%)$ & $1(10 \%)$ & $\begin{array}{l}\text { S-1 alone (or) S-1 + } \\
\text { cisplatin (or) S-1 + } \\
\text { docetaxel }\end{array}$ & $100 \%$ & $100 \%$ & 29.6 \\
\hline $\begin{array}{l}\text { Morgagni } \\
\text { et al. } \\
2018[23]\end{array}$ & Italy & 33 & $\begin{array}{l}8 \\
(24.2 \%)\end{array}$ & $\begin{array}{l}11 \\
(33.3 \%)\end{array}$ & $2(6.1 \%)$ & $2(6.1 \%)$ & - & ECF (or) DOX & $91.9 \%$ & $66.7 \%$ & $38 .($ \\
\hline $\begin{array}{l}\text { Beom et al. } \\
2018[17]\end{array}$ & Korea & 101 & $\begin{array}{l}2 \\
(1.9 \%)\end{array}$ & $\begin{array}{l}35 \\
(34.6 \%)\end{array}$ & $55(54.5 \%)$ & $11(10.9 \%)$ & $\begin{array}{l}20 \\
(19.8 \%)\end{array}$ & $\begin{array}{l}\text { Platinum + } \\
\text { fluoropyrimidine (or) } \\
\text { Taxane + } \\
\text { fluoropyrimidine (or) } \\
\text { Platinum + Taxane + } \\
\text { fluoropyrimidine }\end{array}$ & $75.2 \%$ & $56 \%$ & $26 . c$ \\
\hline $\begin{array}{l}\text { Solaini et } \\
\text { al. } \\
2019[38]\end{array}$ & Italy & 45 & - & $\begin{array}{l}3 \\
(6.7 \%)\end{array}$ & $38(84.4 \%)$ & $4(8.9 \%)$ & - & $\begin{array}{l}\text { Cisplatin + 5-FU (or) } \\
\text { ECF (or) DOX }\end{array}$ & $91.1 \%$ & $67 \%$ & $15 . c$ \\
\hline $\begin{array}{l}\text { Li et al. } \\
2019[39]\end{array}$ & China & 81 & - & $\begin{array}{l}60 \\
(74.1 \%)\end{array}$ & $8(9.8 \%)$ & $4(8.8 \%)$ & $\begin{array}{l}3 \\
(3.7 \%)\end{array}$ & $\begin{array}{l}\text { Oxaliplatin + 5-FU or } \\
\text { DOX }\end{array}$ & NR & $81.4 \%$ & $15 . \varsigma$ \\
\hline $\begin{array}{l}\text { Ramos et } \\
\text { al. 2019[8] }\end{array}$ & Brazil & 16 & $\begin{array}{l}10 \\
(62.5 \%)\end{array}$ & $4(25 \%)$ & $1(6.2 \%)$ & $1(6.2 \%)$ & - & $\begin{array}{l}\text { Capacetabine + } \\
\text { Platinum (or) mFLOX } \\
\text { (or) Capacetabine + } \\
\text { oxaliplatin (or) }\end{array}$ & $81.3 \%$ & $81.3 \%$ & 11.2 \\
\hline
\end{tabular}




\begin{tabular}{|c|c|c|c|c|c|c|c|c|c|c|c|}
\hline & & & & & & & & $\begin{array}{l}\text { paclitaxel + } \\
\text { carboplatin }\end{array}$ & & & \\
\hline $\begin{array}{l}\text { Present } \\
\text { study }\end{array}$ & India & 26 & $\begin{array}{l}26 \\
(100 \%)\end{array}$ & 3 & - & $1(3.8 \%)$ & - & $\begin{array}{l}\text { DOX (or)EOX (or) } \\
\text { FLOT }\end{array}$ & $100 \%$ & $55.3 \%$ & 18.4 \\
\hline
\end{tabular}

${ }^{a}$ No of patients undergoing surgical intervention after neoadjuvant chemotherapy. ${ }^{b}$ Percentage represents the number of patients undergoing $\mathrm{D} 2$ dissection among curative surgeries. 'Median overall survival (OS) of patients undergoing RO resection. NR: Not reported; ECF: Epirubicin + Cisplatin + 5-FU; DOX: Docetaxel + Oxaliplatin + Capacetabine; EOX: Epirubicin + Oxaliplatin + Capacetabine; FLOT: 5-FU + Leucovorin + Epirubicin + Oxaliplatin + Docetaxel.

\section{Figures}

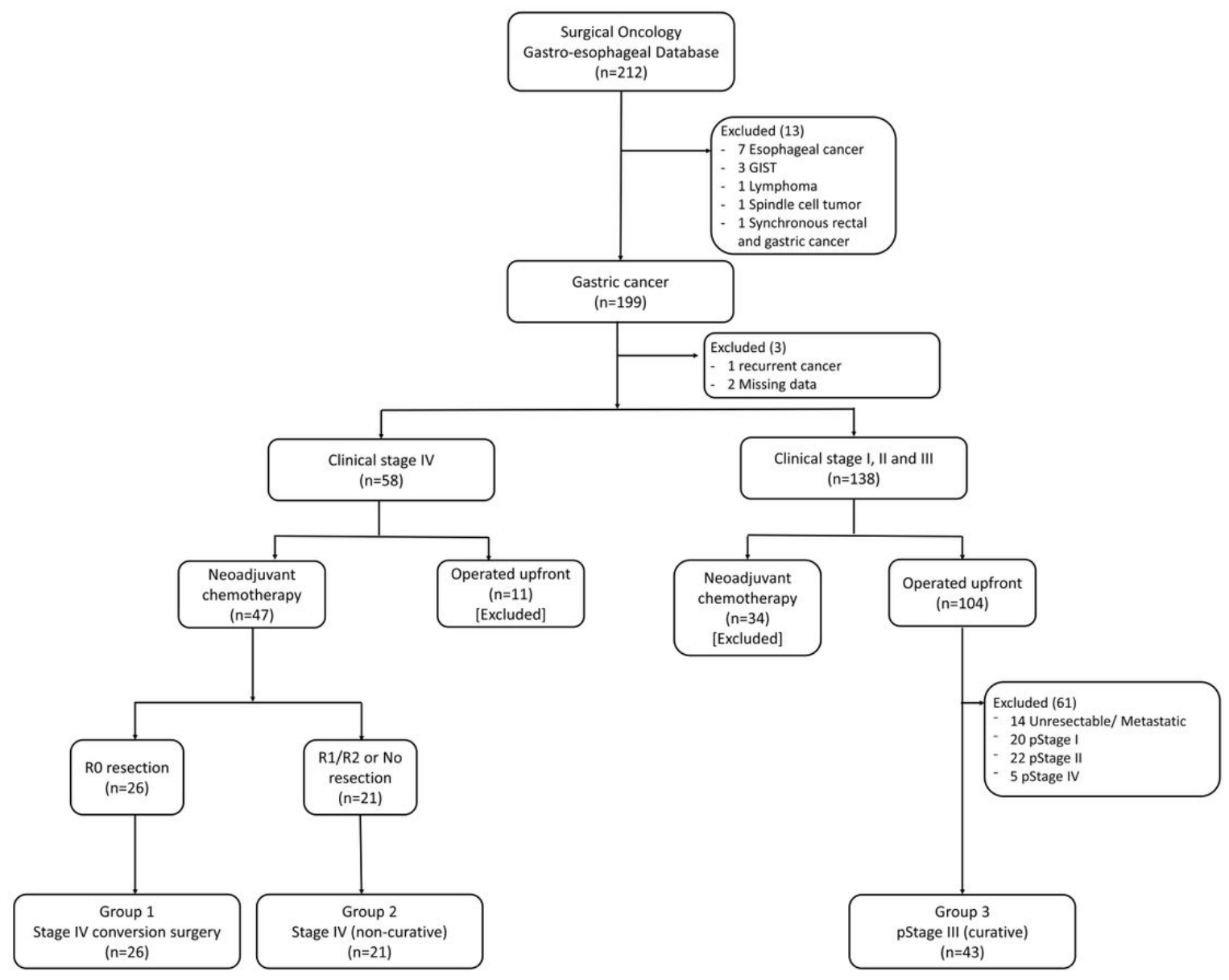

Figure 1

Consort flow of study groups. 

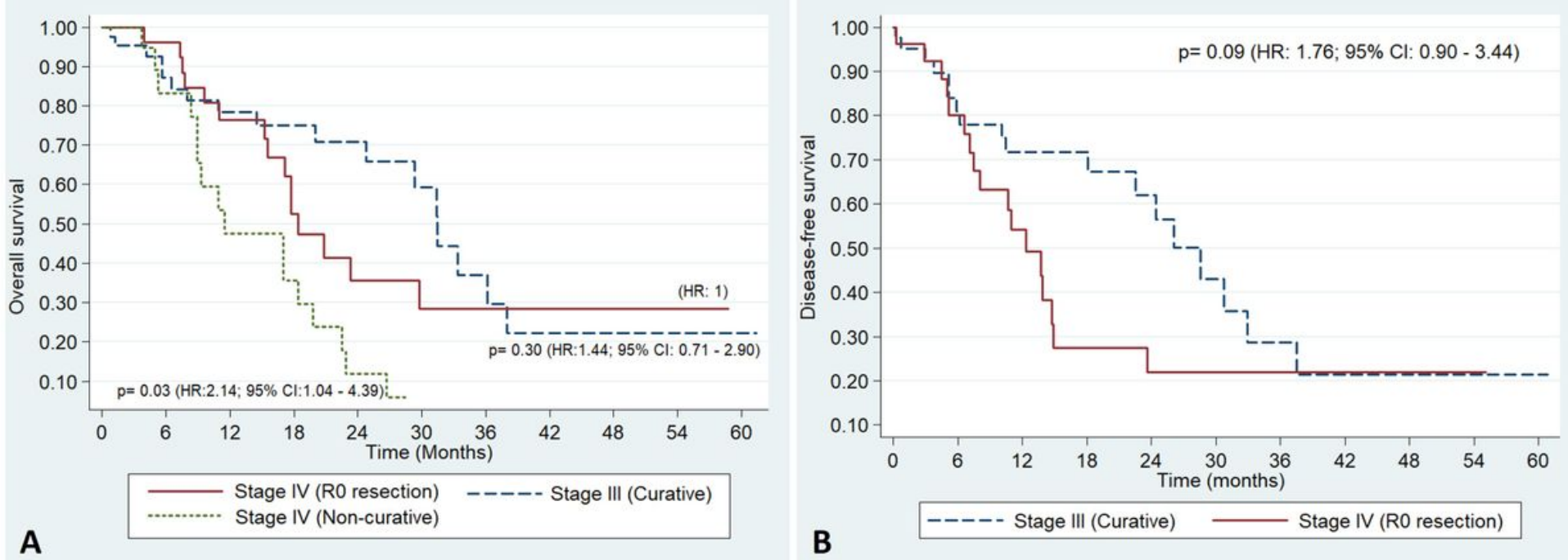

Figure 2

Kaplan-Mier survival curves. A: The overall survival in Stage IV R0 resection (Group 1) is significantly higher than Stage IV noncurative (Group 2) with a p-value of 0.03. No statistical difference was seen in Stage IV R0 resection (Group 1) and Stage III Curative (Group 3) with a p-value of 0.30. B: No statistical difference was seen in the disease-free survival of Stage IV R0 resection (Group 1) and Stage III Curative (Group 3) with a p-value of 0.09. 